\title{
Russia through the Eyes of the Tagores: Travelogues of Rabindranath and Saumyendranath
}

\author{
Sajal Dey \\ Department of Russian Studies, the English and Foreign Languages University, Shillong \\ Campus, Umshing-Mawkynroh, Shillong, Meghalaya, India.Email: sajaldeyo7@gmail.com
}

\begin{abstract}
Two Tagores, two visionaries; one as a poet-educationist, another as a revolutionary-politician, both from colonial India, then reeling under the British yoke, visited Russia at about the same time. While the elder Tagore, Nobel-laureate Rabindranath, was moved by the huge scale of development, mainly on the educational front, -- the younger and the more rebellious one, Soumyendranath, studied deeply, paused, and raised questions, debated and disputed the gap between the so-called socialist theory and practice in Soviet Russia. Rabindranath wanted to visit post-revolution Russia for quite some time. After a few futile attempts his desire was ultimately fulfilled in 1930. What he primarily wanted to see was the all-embracing spread of education in the Soviet system and its results. His Russiar Chithi, or Letters from Russia bears testimony to his impression of the new 'awakened' Russia. In the very first line of his first letter from Moscow he writes, "In Russia at last! Whichever way I look, I am filled with wonder." In spite of a few adverse comments that he made later on, this feeling of 'wonder' about Russia lasted throughout the collection. Soumyendranath, grandson of Rabindranath's elder brother Dwijendranath, was one of the pioneers of communist movement in India. After a short period of romance with Gandhism that failed to answer some of the basic questions he had in his mind, Soumyendranath was attracted to socialism. He went to Russia in 1927, took lessons of communism from Bukharin himself, got admitted in the Lenin course at the Marx-Engels Institute, and also learned Russian language very well. A formidable intellectual, Soumyendranath never faltered to express his opinion even in Stalinist Russia. He debated with Bukharin, disputed Gorky's opinion regarding proletarian literature, and opposed the Kuusinen Thesis in the sixth world congress of Comintern held in 1928. Shortly after that he went away, but came back to Russia in 1930 along with Rabindranath. His travelogue Jatri or The Wayfarer, among other things, carries his impression of Russia.

In this paper a comparative study of these two outlooks of the two Tagores has been undertaken, showing how these two great minds differed, as far as Russia was concerned, as evident from the travelogues and books they wrote and other related materials. Their personal relationship as well as literary and ideological influences on each other is one of the pivotal points of investigation. The important thing kept in view was that, both of them in their own way represented the country they belonged to, and their lifelong mission was emancipation of their homeland and its people, again in their own distinctive ways.
\end{abstract}

Keywords: Russian revolution, socialism, Tagores, Rabindranath, Soumyendranath

Rabindranath Tagore was not an ordinary man, not even a poet only; he was a polymath in the true sense of the word. A writer, thinker, philosopher, educationist, linguist, artist and lyricist; he was a complete whole. And of course a patriot too, in spite of his famed 'Internationalism'. Towards the end of this paper I shall highlight this point as a reply to some of the questions raised by the contemporary ultra-nationalists. As for now, as a humble reader of Rabindranath, and a student of Russian Studies as well, from whatever I read of Rabindranath and his Russian

(C) AesthetixMS 2020. This Open Access article is published under a Creative Commons Attribution Non-Commercial 4.o International License (http://creativecommons.org/licenses/by-nc/4.o/), which permits non-commercial re-use, distribution, and reproduction in any medium, provided the original work is properly cited. For citation use the DOI. For commercial re-use, please contact editor@rupkatha.com. 
"pilgrimage", I shall undertake to make a few points. At the same time I shall make an attempt to compare this trip with another prominent person's journey, a person who has been mostly ignored till date. Since I shall be talking about and comparing two Tagores, the word 'Tagore' might appear confusing, and I will mention them mostly by their first names.

That Rabindranath Tagore visited Russia in 1930 is a well-known historical fact and much celebrated by the scholars interested in International relations, Indo-Russian relations, and languages, literatures and cultures of both the countries. Tagore's Russiar Chithi or Letters from Russia (May 1931') bears testimony to his impression of the post-revolution Russia. The collection was read, talked about, cited, discussed, debated and analysed many times. What is less known and even almost unnoticed is the fact that he was not alone, but accompanied by a few other important personalities. One of them was Saumyendranath, grandson of Rabindranath's elder brother Dwijendranath. One of the pioneers of the communist movement in India, Saumyendranath was an internationally acclaimed communist intellectual, next only to M. N. Roy $^{2}$. He represented India in the Sixth World Congress of the Comintern ${ }^{3}$, was jailed by German, British and Indian governments, was a regular writer of the literary group Kalikalam ${ }^{4}$ and in 1934 founded his own political party named Communist League, which later on became RCPI ${ }^{5}$. But being born a Tagore, having talents and living in the times of the great Tagore, is a very difficult proposition. We do not talk much about this Tagore. Do we?

In this paper I shall restrict myself mostly to their Russia visit, their views on the then Russia and their mutual relationship in forming each other's views and world outlooks. The very first point I would like to raise is that Rabindranath's Russiar Chithi was written in the form of letters, which were actually sent by him to some of his friends and eminent persons. Among them were Rathindranath Tagore (his son), Prasantachandra Mahalanabis, Nirmalkumari Mahalanabis, Surendranath Kar, Sudhindranath Datta, Nandalal Basu, Ramananda Chattopadhyay, Kalimohan Ghosh et al. Later on these were combined and published as a book. On the other hand Saumyendranath's Jatri (The Wayfarer, $1950^{6}$ ) was basically an autobiography, spanning many years of his eventful life. But a considerable part of it deals with his Russia visit and the Russian question in details.

These two Tagores, two visionaries; one a poet-educationist, the other a revolutionarypolitician, both from colonial India, then reeling under the British yoke, visited Russia at about the same time. While the elder Tagore, Nobel-laureate Rabindranath, was moved by the huge scale of development, mainly on the educational front, -- the younger and the more rebellious one, Saumyendranath, studied deeply, paused, and raised questions, debated and disputed the gap between the so-called socialist theory and practice in Soviet Russia. This is not to say that Rabindranath did not criticize or pass adverse comments on the Russian system, but he was basically amazed with the Soviet achievement.

Rabindranath wanted to visit post-revolution Russia for quite some time. After a few futile attempts his desire was ultimately fulfilled in 1930. What he primarily wanted to see was the allembracing spread of education in the Soviet system and its results. His Russiar Chithi, or Letters from Russia bears testimony to his impression of the new 'awakened' Russia. In the very first line of his very first letter from Moscow he writes, "In Russia at last! Whichever way I look, I am filled with wonder. It is unlike any other country. It is radically different. From top to bottom they are rousing everybody up without distinction" (Tagore, R. 196o, p. 1). In spite of a few harsh remarks that he made later on, this feeling of 'wonder' about Russia lasted throughout the collection, as I already mentioned. Such expressions from Saumyendranath would have been a rarity. 
The case of Saumyendranath was different. Born in the Tagorean cultural and social ambience, he was initially inspired by Mahatma Gandhi and his call that roused many Indians, including the poor, ordinary, toiling and farming mass. But after a short period of romance with Gandhism that failed to answer some of the basic questions, Saumyendranath had in his mind, he was attracted to socialism. He went to Russia in 1927, took lessons of communism from Bukharin ${ }^{7}$ himself, got admitted in the Lenin course at the Marx-Engels Institute ${ }^{8}$, and also learned Russian language very well. A formidable intellectual, Soumyendranath never faltered to express his opinion even in Stalinist Russia. He debated with Bukharin, disputed Gorky's opinion regarding proletarian literature, and opposed the Kuusinen Thesis ${ }^{9}$ in the sixth world congress of Comintern (Communist International) held in 1928 in Moscow. Shortly after that he went away, but came back to Russia in 1930 along with Rabindranath. It is therefore no wonder that the views of Saumyendranath would significantly differ from that of Rabindranath. Saumyendranath was a political theorist, a revolutionary, a man from the field, from the streets literally. Moreover he stayed longer in Russia and the vicinity, in the thick of the important political and social events; to better understand and analyze the so-called Russian question ${ }^{10}$. He was a kind of insider, not exactly a traveller like Rabindranath. Also, Rabindranath was an honoured invited guest with worldwide fame, whereas Saumyendranath was a young explorer.

Rabindranath's Russia visit was a short one, lasting only for fourteen days; from $11^{\text {th }}$ September to $25^{\text {th }}$ September, 1930. He did not meet any big literary figure or political leader and he did not go anywhere outside Moscow. Even the great city of St. Petersburg and its worldfamous Hermitage Museum remained unseen by him. Tolstoy's Yasnaya Polyana was situated at a distance of 200 kilometers only from Moscow. But he was not supposed to pay a visit to that famous abode too. (In a different work of mine, I mentioned the reason behind it.") He was shown mainly what the Soviet authorities wanted to be shown to him. It was more of a conducted tour, not an exploration. (Basu, 1983 p. 10) In spite of that, a great thinker that he was, Rabindranath could correctly spell the problems associated with the Soviet system that was apparently producing marvellous results in education and other sectors. Some of his comments on Russia proved to be prophetic in the long run, although the portions containing adverse comments by Rabindranath were severely edited and never published in Russia until much later. It was only in 1986 that the deleted portions were translated into Russian and published, and amazed the new generation of Russian readers with the accuracy of his analysis and prediction. (Som, 2014, p. 149).

Before leaving Moscow, in an interview with the famous Russian newspaper Izvestiya, Rabindranath said:

But I find here certain contradictions to the great mission you have undertaken. Certain attitudes of mind are being cultivated which are contrary to your ideal.

I must ask you: Are you doing your ideal a service by arousing in the minds of those under your training anger, class hatred and revengefulness against those not sharing your ideal, against those whom you consider to be your enemies? ...for the sake of humanity I hope that you may never create a vicious force of violence which will go on weaving an interminable chain of violence and cruelty. Already you have inherited much of this legacy from the Tsarist regime. It is the worst legacy you could possibly have. You have tried to destroy many of the other evils of that regime. Why not try to destroy this one also?" (as cited in Som, 2014, p. 131). 
This was a severe blow in spite of his admiration for other achievements of the Soviet system. For obvious reasons this was not published in Izvestiya, but a few weeks later on $30^{\text {th }}$ October 1930 it came out in Manchester Guardian when Rabindranath was in America. (Som, 2014, p. 131)

In Jatri, Saumyendranath describes in gruesome details his experience of Stalinist Russia. A part of this book can very well be the theme of a political thriller or a horror movie. Political turmoil, controversies; personal, group and political conspiracies; rolling of heads, exiles, secret killings in the name of justice, the internal problems and feuds of the delegates of the Comintern etc. take up a considerable number of pages of this very important document. It includes, among other things, the other faces of some of the Indian politicians too. Of course I am not going to say that there were no comic relief or pleasant episodes in the entire book, but the basic shade was that of a burning charcoal.

Saumyendranath was not ready to accept the Russian Nationalism propagated and forced by Stalin's regime as Communist Internationalism. It would have been absolutely difficult to call his Russian experience a "pilgrimage"12, as Rabindranath did. It is not to opine that he learnt nothing from there. But he always paid heavy price for being uncompromising in thought, speech and action. Even later on, his party RCPI was not that successful as a political organization as compared to its big Indian brothers CPI, CPI(M) etc. Surprisingly, or should I say, characteristically, most of the communist historians were silent on this great soul. On their part, Soviet authorities too wanted to erase the memory of Saumyendranath as far as possible. In the book Traditions of Great Friendship published as late as in 1985, authors Yevgeni Chelyshev and Alexei Litman write: "Tagore was rendered great assistance in getting to know Soviet reality more deeply by those who accompanied him on his journey: his secretaries Aryanayakam and Amiya Chakravarti, his friend Harry Timbers and Margot Einstein, daughter of the famous German physicist" (1985, p. 188). There is absolutely no mention of Saumyendranath, the other Tagore. This statement, therefore, becomes not really a mistake, but a strategic deletion! Nobody was acquainted with Russia better than Saumyendranath in the whole group.

Rabindranath and Saumyendranath influenced each other, in spite of their age difference. Rabindranath was born in 1861, Saumyendranath in 1901. Saumyendranath was born in Jorasanko Thakurbari in a milieu that was filled with the "light and aroma"13 of Rabindranath (in his own words). He grew up sustaining on that "light and aroma", on the poetry, songs, dances, acting, speeches, writings of Rabindranath. This shaped him, gave him an initial form. After that as a grown-up man, Saumyendranath was able to look at him as a public personality from a distance, even at times to criticize him without hesitation. They traversed two different paths in their lives. Sometimes this even apparently put their mutual love and respect to test. One famous example is his letter written to Rabindranath on $1^{\text {st }}$ November 1933, literally thrashing him for his reported support to Nazism, when Rabindranath supposedly said something in support of the German Vice-Consul's speech in Santiniketan (Tagore, S. 2007, p. 95). He was vocal about the apparent controversy in Rabindranath's stand where he reportedly opposes Italian fascism, but supports German Nazism. These two, in Saumyendranath's opinion, were one and the same thing. Saumyendranath was one of those very few people who had the guts to do that to Rabindranath.

When Saumyendranath's efforts resulted in the formation of the Indian chapter of 'League against Fascism and War' in 1937, Rabindranath became the President and he took charge as the general secretary of the organization. Among other members of this anti-fascist association were Prof. K. T. Shah, Jayaprakash Narayan, S. A. Dange et al. In fact, Saumyendranath was the lone communist who raised his voice, wrote and organized people against fascism continually in the 30's of the last century (cited in Tagore, S. 2007, pp. $99-100$ ). 
Saumyendranath's love and admiration for Rabindranath was indisputable. Once, while discussing about world literature, he had categorically declared that there existed not a single writer in Soviet Russia equaling the standard of Romain Rolland, Rabindranath Tagore, Thomas Mann et al (Tagore, S. 1975, p. 146). His Russian friends could not believe what they heard. For them these writers represented bourgeois culture, their works were bourgeois literature. They considered someone like the fellow Russian Demyan Bedny ${ }^{14}$ a great poet. Saumyendranath was not ready to accept the types of Demyan Bedny, the official Soviet poet, as poets at all. He called them poster-makers and slogan-writers. It was not an easy thing to do in that space and time. But he did express his opinion, not only once, but on several occasions and issues; and dangerously survived.

But was Saumyendranath as querulous or as difficult a person as many of his communist friends, both Indian and Russian, thought? Let us quote from two other well known persons' writings. Jawaharlal Nehru writes, opposing his stance on Gandhi, but still maintaining that:

Mr. Saumyendranath Tagore is one of our young comrades in India for whom I have the greatest respect. Ardent, clear-headed, devoted to the cause of freedom of the masses, anything that he says or writes must deserve attention. (as cited in Bose, 2007, p. 51).

In a letter to Mahatma Gandhi, dated $4^{\text {th }}$ April 1934, Romain Rolland writes about Saumyendranath:

This young man is hostile to your ideas, but in his hostility I believe there is much of his old love for you and you would be the first to esteem and pity him for his agonizing sincerity which suffers passionately at the suffering of India... I wish you could meet him. Saumyendranath is a noble force, idealistic and pure, ready for every sacrifice; you might be reconciled with him and win him back. (as cited in Bose, 2007, p. 51).

Rabindranath was a Nobel laureate, an artist and a polymath. It would seem very inappropriate to compare him with Saumyendranath, who basically belonged to a different field. But Saumyendranath too was an outstanding personality, as we have already seen. There remains some more information to share, even if we talk briefly about him. He was the first to translate Communist Manifesto into Bangla and publish it in the magazine Ganavani in $1926^{15}$. He also translated the communist international song 'International' into Bangla, keeping the tune intact ${ }^{16}$. A graduate in economics from the legendary Presidency College of Calcutta, Saumyendranath was a good singer, translator and an expert of literature, art and music; something one can rarely find in a political theorist. He was an excellent orator; delivered speeches in Bangla, English, Hindi, Russian and German. His grasp of Sanskrit too is well documented in his essays in which he appreciates and analyses Kalidasa, although one of them created some debate because of Saumyendranath's distinctive perspective on the ancient poet. (Bose, 2007, p. 194) Saumyendranath's Bangla and English publications number around eighty; and we are yet to determine the exact number of publications in other languages, including Hindi, Russian, German and French. He set up an organization called Baitanik in 1949 for promoting research and studies in Rabindrasangeet, and was the first president of Tagore Research Institute, founded in 1965 (Bose, 2007, p. 33).

There are sufficient reasons to believe that it was mainly because of Saumyendranath's influence that Rabindranath felt interested in Russia, communism and the great Soviet experiment. So, it was no wonder that Rabindranath would seek his company while travelling to and inside Russia. But afterwards, when the edited version of Letters from Russia and Rabindranath himself were used as great tools for developing Indo-Soviet relations in many 
spheres including political, cultural, military and industrial; Saumyendranath was thrown into deliberate oblivion by both sides. Even the mainstream Indian communists hardly ever mentioned his name, and when they did so, often tried to malign him.

The point that is very important is that, both of them in their own way represented the country they belonged to, and their lifelong mission was emancipation of their homeland and its people, again in their own distinctive ways. Some examples can be cited: Rabindranath's Santiniketan and Sriniketan projects, his efforts in creating the Co-Operative System in the social domain way back in 1927 ${ }^{17}$; Saumyendranath's Ganavani, Baitanik and RCPI. In this they were more nationalistic than international, more rooted than universal. Although Rabindranath's humanism and Saumyendranath's communism both are considered to be kinds of universalism, but what they did for their country and its people makes them nationalistic first of all. Their patriotism was in no way opposed to the kind of internationalism/universalism they professed; it was part of a greater ecosystem.

Obviously the sphere and focus of their activities were different. A poet-educationist and a revolutionary-politician would not strive to achieve the same thing in the same manner. Rabindranath was able to bring the world under the one nest called Visva-Bharati, and was undoubtedly the greatest icon of Indian literature and culture; Saumyendranath planted in India the seeds from his knowledge and experience of communist movements elsewhere in the world, and maintained a healthy synthesis of politics and culture. It all went into building a new India; India of their dreams, of their belief systems. It would be very difficult to call them anti or nonnationalistic, as some extreme right wing groups are trying to do. If the geopolitical scenario is different today and the same country is divided into more than one 'nations' hating and fighting against each other, that cannot be considered as their fault. Rabindranath had warned us enough against this western concept called 'nation' or 'nationalism' long ago. He would have never wanted his 'swadeshi samaj'18 to undergo such a horrific ordeal.

\section{Notes}

${ }^{1}$ The original Bengali collection was published as a book on $25^{\text {th }}$ of Baisakh, 1338 Bangabda (the Bengali calendar); i.e. May 1931. But the letters were published serially in the Bengali journal Prabasi before that.

${ }^{2}$ Narendra Nath Bhattacharya, famously known as M. N. Roy (Manabendra Nath Roy), political activist, theorist and philosopher. He was a founder of the Mexican Communist Party, apart from the Communist Party of India.

${ }^{3}$ The Communist International, known also as the Third International (1919-1943), was an International organization that advocated world communism. The organization held seven World Congresses in Moscow between 1919 and 1935 .

${ }^{4}$ Kalikalam (1926 - 1930) was the name of both the Bengali literary group and the journal they published.

${ }^{5}$ The Revolutionary Communist Party of India, was founded as Communist League by Saumyendranath Tagore in 1934 breaking away from the Communist Party of India (CPI). It was further split in 1948 into RCPI (led by Pannalal Dasgupta) and RCPI (Tagore) led by Saumyendranath. Pannalal wanted to carry out a general armed insurrection, which according to Saumyendranath was a premature idea in the then Indian context.

${ }^{6}$ The first edition of Jatri was published by Abhijan Publishing House in 1950 (1357 Bangabda), and the enlarged later edition was published by General Printers and Publishers in November 1975 (1382 Bangabda). 
${ }^{7}$ An economist and theoretician, Nikolai Ivanovich Bukharin (1888 - 1938) was one of the prominent Russian communist leaders and close aides of Lenin. He was a member of the Politburo and was also heading the Comintern when Saumyendranath reached Russia in 1927. Bukharin was ousted as a Rightist in 1929 and executed in 1938 after a show trial.

${ }^{8}$ Established in 1919 as the Marx-Engels Institute, this institute does not exist anymore. It was merged with the Lenin Institute in November 1931, renamed many times and finally officially terminated in November 1991 following the fall of the Soviet Union.

${ }^{9}$ Otto Wilhelm Kuusinen (1881 - 1964) was a Finnish, and later, Soviet politician. A close aide of Stalin, Kuusinen in his thesis alleged that forming a party of workers and peasants is wrong as they represent two different classes. According to him, this hampers the revolutionary labour movement. Saumyendranath criticised this thesis and placed his own logic (Bose, 2007,p. 77). He also opposed Kuusenin's proposal that the bourgeoisie should be considered as an associate and supporter of revolution against the colonizers in the colonized countries. Saumyendranath tried to explain that the role of the bourgeoisie has always been counter-revolutionary in the freedom movement of the colonies (Bose, 2007, p. 78).

${ }^{10}$ The Russian question had two main components: 1) Whatever was happening in Soviet Union at that time, was it true socialism at all? 2) Was it possible to have socialism in one country only?

${ }^{11}$ See the soon to be published paper Sajal Dey 2019, "Tagore and Chakravarty: Two Perspectives on Russia of the 1930s" in Russian Studies in the XXI Century: Current Trends and Innovations (Hyderabad: Dept. of Russian, EFLU). Somendranath Basu and Sergei Serebriany have also specified their viewpoints on this issue.

${ }^{12}$ Rabindranath's use of the word 'pilgrimage'(tirthadarshan) should not be considered to be having a religious or ritualistic connotation. It has more to do with exploration of the unseen, unknown, unexperienced and unlearned. Som explains it in details with quotations from Rabindranath $(132-35)$.

${ }^{13}$ In Bangla the words were "alo o surabhi"(as cited in Bose, 2007, p. 216).

${ }^{14}$ Demyan Bedny was the penname of Soviet writer, poet and public figure Efim Alekseyevich Pridvorov $(1883$ - 1945), who was basically a follower of Stalin's line. He adopted this penname after the publication of his poem Of Demyan Bedny. 'Bedny' in Russian means 'poor'. There is no doubt in the minds of most of the contemporary critics and readers that he really was very 'poor' as a poet.

${ }^{15}$ It was published in Bangla as Sadharan Swatwabadir Istahar (Bose, 2007, p. 17).

${ }^{16}$ It was one of the songs in the book Lal Nishan that was confiscated by the then government as soon as it reached India in about 1931 (Bose, 2007, p. 22).

${ }^{17}$ See “Tagore and Co-Operative Movement”, https://vbccsl.org/index.php/about/vbccsl

${ }^{18}$ Elaborating on Rabindranath's perception of the terms like 'nation', 'nationalism' and 'swadeshi samaj' requires a full-fledged discussion, which is not possible within the framework of the present article.

\section{Books and References}

\section{Bangla}

Basu, Somendranath. (1983). Rabindrnath O Russiar Chithi. Kolkata: Tagore Research Institute.

Bose, Manjula. (2007). Saumyendranath Tagore: Karme O Monane. Kolkata: Tagore Research Institute.

Dasgupta, Apurba. (2012). Rabindranather Bolshevik Abhignyata. Bhavna-Chinta, 39(4), 1-4.

Ghosh, Subhamay. (1961). Soviet Unione Rabindranath. Santiniketan: Rabindra-Bhavan (Visva-bharati).

Nath, Abha. (200o). Samajchintay Rabindranath. Kolkata: Tagore Research Institute.

Sen, Ashok. (2005). Rajnitir Pathakrome Rabindranath. Bangadarshan 10, 41-85. 
Sen, Ashok. (2006). Rajnitir Pathakrome Rabindranath. Bangadarshan 11, 35-125.

Som, Arun. (2014). Rabindrachetanay Russia O Rabindracharchay Russia. Kolkata: Shreya.

Tagore, Saumyendranath. [(1934) 2007]. Fascism. Kolkata: Monfakira.

Tagore, Saumyendranath. (1975). Jatri. Kolkata: General Printers and Publishers.

\section{English}

Chelyshev, Yevgeni and Alexei Litman. (1985). Traditions of Great Friendship. Moscow: Raduga.

Gnatyuk-Danil'chuk, A. P. (1986). Tagore, India and Soviet Union: A Dream Fulfilled. Kolkata: Firma KLM.

Serebriany, Sergei. (2014). Russia. In M. Kampchen and I. Banga (Eds.), Rabindranath Tagore: One Hundred Years of Global Reception. Hyderabad: Orient Blackswan, pp. 203-35.

Tagore, Rabindranath. (1960). Letters from Russia. (Sasadhar Sinha, Trans.). Kolkata: Visva-Bharati.

\section{Russian}

Kashin, Valery. (2009). Rabindranath Tagore o Rossii. Koloss Chandragupty. Moscow: VK.

Zagorodnikova, T. N., V. P. Kashin and T. L. Shaumyan. (2011). Obraz Rossii vobshchestvennom soznanii Indii: proshloye i nastoyashchyeye. Moscow: RAS.

Sajal Dey hails from Kolkata, West Bengal and received his education at the universities of Kolkata (CU), Santiniketan (Visva-Bharati) and Hyderabad (CIEFL/EFLU). He has authored four collections of poems and translated an award-winning Assamese novel into Bangla for Sahitya Akademi, New Delhi. Sajal has translated short stories, plays and poems from Russian, Hindi and English for a number of literary and scholarly journals. His academic interests include Rabindranath, Linguistics and Foreign Language Studies, apart from his specialization - Russian Studies. Sajal got his PhD degree in Russian from Bhasha Bhavana, Visva-Bharati, Santiniketan and is currently teaching Russian on the picturesque Shillong campus of the English and Foreign Languages University. He is also a member of the FEB (Indian Esperanto Federation) committee and is presently engaged in translating the first Esperanto autobiography written by an Indian into Bangla. 